\title{
Epigenetic dysregulation in pituitary tumors
}

\author{
Omair A Shariq ${ }^{1}$ \& Kate E Lines*,1 iD \\ ${ }^{1}$ OCDEM, Radcliffe Department of Medicine, University of Oxford, Churchill Hospital, Oxford, OX3 7L, UK \\ *Author for correspondence: kate.lines@ocdem.ox.ac.uk
}

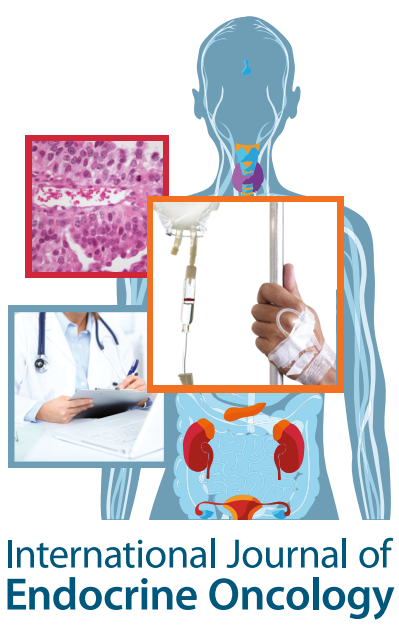

Pituitary tumors are common intracranial neoplasms associated with significant morbidity due to hormonal dysregulation and neurologic symptoms. Somatic mutations are uncommon in sporadic pituitary adenomas, and only few monogenic conditions are associated with pituitary tumors. However, increasing evidence suggests that aberrant epigenetic modifications are found in pituitary tumors. In this review, we describe these mechanisms, including DNA methylation, histone modification and microRNA expression, and the evidence supporting their dysregulation in pituitary tumors, as well as their regulation of protumorigenic genes. In addition, we provide an overview of findings from preclinical studies investigating the use of histone deacetylase inhibitors to treat pituitary adenomas and the need for further studies involving epigenetic drugs and functional characterization of epigenetic dysregulation.

First draft submitted: 14 June 2019; Accepted for publication: 15 July 2019; Published online: 3 October 2019

Keywords: DNA methylation $\bullet$ histone modification $\bullet$ microRNA $\bullet$ neuroendocrine and pituitary carcinoma

Pituitary tumors are common neoplasms accounting for $10-15 \%$ of primary intracranial tumors $[1,2]$. Approximately $75 \%$ are functional adenomas that secrete excess amounts of a hormone, including prolactinomas that secrete prolactin (PRL), somatotrophinomas that secrete growth hormone $(\mathrm{GH})$, corticotrophinomas that secrete adrenocorticotropin $(\mathrm{ACTH})$ or thyrotrophinomas that secrete thyroid-stimulating hormone. The remainder are clinically nonfunctional (NF) and present with neurological symptoms or pituitary hypofunction, secondary to mass effect of the enlarging gland [1-3]. Malignant pituitary carcinoma is rare, with the majority ( $>99 \%$ ) of pituitary tumors being benign adenomas. Benign adenomas are, however, still a source of significant morbidity due to the systemic sequelae of hormonal dysregulation and the need for surgical, radiological and chronic medical therapy for disease control [1-3].

Studies investigating the molecular basis of pituitary adenomas occurring in hereditary syndromes such as multiple endocrine neoplasia (MEN1), Carney complex and familial-isolated pituitary adenoma, have revealed single causal germline mutations in the genes MEN1, PRKARIA and AIP, respectively [4-6]. However, only 5\% of pituitary adenomas are familial, with the majority being sporadic in origin and associated with a paucity of genetic mutations from whole exome/genome sequencing [3,7-9]. To date, recurrent somatic mutations have been identified in only four genes; USP8, USP48, BRAF in a subset of corticotrophinomas [10-12] and GNAS in somatotrophinomas [13]. Thus, although recurrent somatic mutations and rare inherited variants may account for the development of a small proportion of pituitary adenomas, mechanisms other than genetic mutation are likely to be driving factors.

Increasing evidence has shown aberrant epigenetic modifications in pituitary tumors. Epigenetic modifications, which cause changes in gene expression without altering the underlying DNA sequence, include DNA methylation, histone modifications and microRNA (miRNA) activity (Figure 1). The combined influence of DNA methylation and histone modification regulates access of transcriptional machinery to DNA, resulting in inappropriate overor underexpression of genes implicated in tumor formation and progression [3]. Additionally, miRNAs cause translational suppression or direct degradation of target mRNAs at the post-transcriptional level [3]. Studies that implicate these mechanisms in pituitary tumorigenesis are discussed in this review.

\section{DNA methylation}

DNA methylation is the most widely studied epigenetic modification in humans, with its mechanisms first described over 30 years ago. DNA methylation involves the transfer of a methyl group from S-adenosylmethionine to the

Future Medicine 


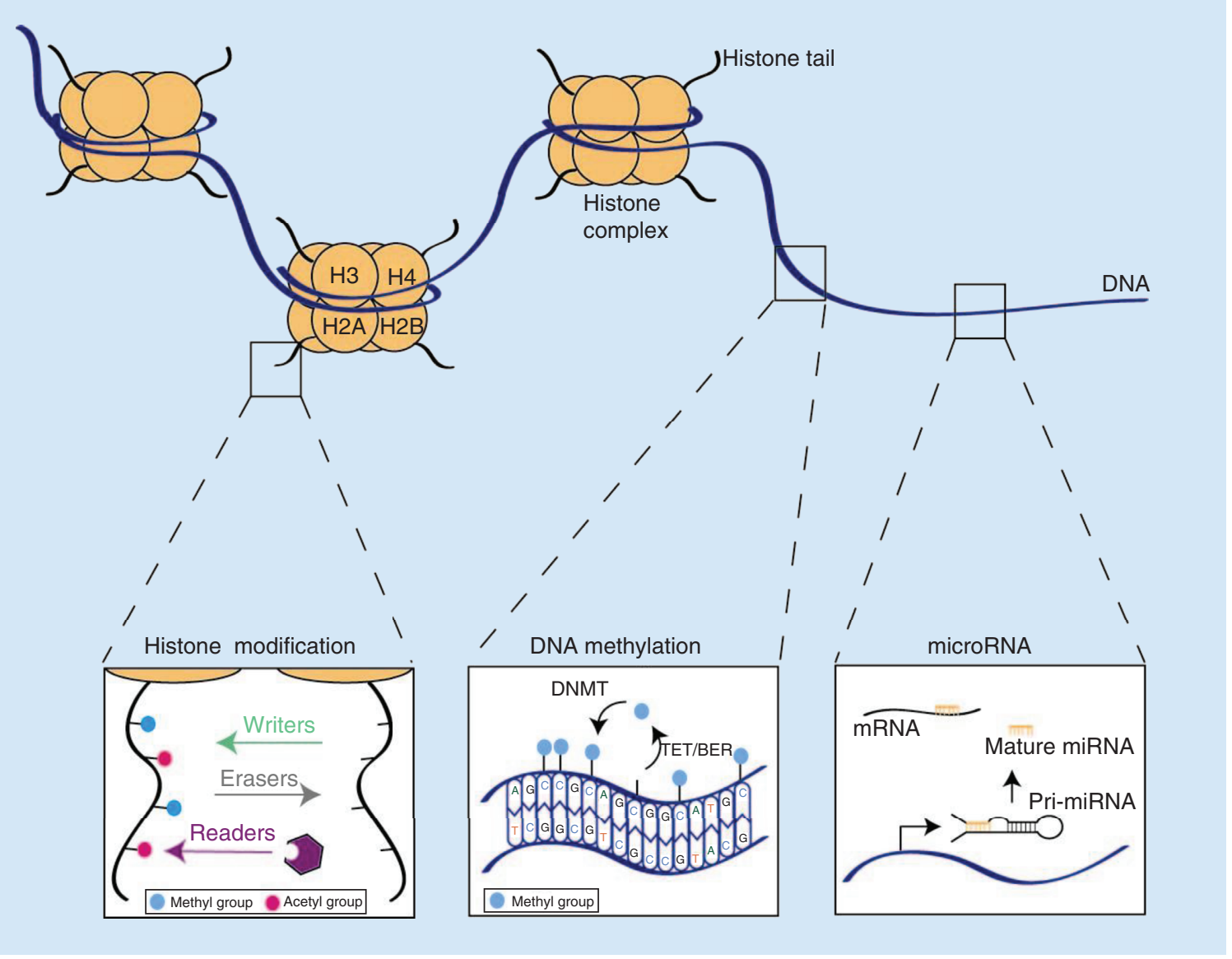

Figure 1. Schematic representation of epigenetic mechanisms in pituitary tumors. Epigenetic changes that can alter gene transcription include histone modification, DNA methylation and microRNAs.

BER: Base excision repair; DNMT: DNA methyl transferase; H: Histone; TET: Ten-eleven translocation.

5'-position of cytosine residues, usually of $\mathrm{CpG}$ dinucleotides, which can subsequently be removed by ten-eleven translocation (TET) proteins and base excision repair (Figure 1). The DNA methyltransferase (DNMT) enzymes DNMT3A and DNMT3B mediate de novo DNA methylation patterns, which are maintained by DNMT1 [14,15]. The majority of CpGs are clustered in regions termed 'islands' that are located near transcription start sites at approximately $70-80 \%$ of gene promoters $[16,17]$. Methylation of these regions functionally silences the promoter and its corresponding gene by precluding binding of transcription machinery, or by recruiting methyl-CpG-binding proteins that interact with repressive histone-modifying enzymes [18].

In human pituitary adenomas, a number of genes demonstrate promoter hypermethylation (Table 1). Many are involved in tumor suppressive signaling pathways, including the cell cycle regulator genes $C D K N 1 A\left(\mathrm{p} 21^{\mathrm{Cip} 1}\right)$ [19],

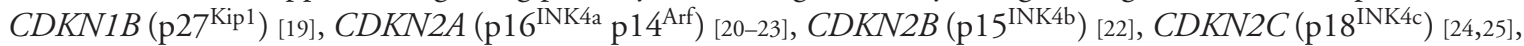
RB1 [19,22,26] and GADD45y [27,28]; the apoptosis genes DAPK1 [29], RHBDD3 (PTAG) [30] and CASP8 [23]; the tumor suppressor genes RASSF1A [31], RASSF3 [32], CDH1 and CDH13 [33]; the growth factor signaling component FGFR2 [34]; and the negative cell growth regulator MEG3 [35]. However, correlation between gene expression and promoter methylation is not always observed and therefore the functional contribution of this methylation is unclear. For example, while STAT3 and NDRG2 were found to be hypermethylated in 11 and $23 \%$ of pituitary adenomas, respectively, no correlation with mRNA expression and clinical characteristics (e.g., invasiveness and recurrence) were seen [36]. Moreover, an analysis of $13 \mathrm{NF}$ adenomas found no correlation between methylation and transcript expression in 9 out of 12 inappropriately methylated genes [37]. This highlights the importance, and difficulty, of determining which genes play key 'driver' roles in initiating and promoting pituitary tumorigenesis via DNA methylation-mediated gene silencing, and which genes act as passive 'passengers'. 
Table 1. Overview of dysregulated epigenetic mechanisms in pituitary tumors.

\section{DNA methylation}

\begin{tabular}{|c|c|c|c|c|}
\hline \multicolumn{2}{|c|}{ Gene } & $\begin{array}{l}\text { Gene expression level in } \\
\text { pituitary }\end{array}$ & Gene function & Ref. \\
\hline \multicolumn{2}{|l|}{$C D K N 1 A$} & Decreased & Cell cycle regulation & [19] \\
\hline \multicolumn{2}{|l|}{$C D K 1 N B$} & Decreased & & [19] \\
\hline \multicolumn{2}{|l|}{$C D K N 2 A$} & Decreased & & [20-23] \\
\hline \multicolumn{2}{|l|}{$C D K 2 N B$} & Decreased & & [22] \\
\hline \multicolumn{2}{|l|}{$C D K N 2 C$} & Decreased & & {$[24,25]$} \\
\hline \multicolumn{2}{|l|}{ P73 } & Decreased & & [23] \\
\hline \multicolumn{2}{|l|}{$R B 1$} & Decreased & & {$[19,22,26]$} \\
\hline \multicolumn{2}{|l|}{$D A P K$} & Decreased & Apoptosis & [29] \\
\hline \multicolumn{2}{|l|}{ RHDD3/PTAG } & Decreased & & [30] \\
\hline \multicolumn{2}{|l|}{ CASP8 } & Decreased & & [23] \\
\hline \multicolumn{2}{|l|}{$G A D D 45 \gamma$} & Decreased & $\begin{array}{l}\text { DNA repair, apoptosis, } \\
\text { cell cycle regulation }\end{array}$ & {$[27,28]$} \\
\hline \multicolumn{2}{|l|}{ RASSF1A } & Decreased & Signal transduction & [31] \\
\hline \multicolumn{2}{|l|}{ RASSF3 } & Decreased & & [32] \\
\hline \multicolumn{2}{|l|}{$C D H 1$} & Decreased & Cell-cell adhesion & [33] \\
\hline \multicolumn{2}{|l|}{$\mathrm{CDH} 13$} & Decreased & & [33] \\
\hline \multicolumn{2}{|l|}{ FGFR2 } & Decreased & Growth factor signaling & [34] \\
\hline \multicolumn{2}{|l|}{ MEG3 } & Decreased & $\begin{array}{l}\text { Cell proliferation, } \\
\text { apoptosis }\end{array}$ & [35] \\
\hline \multicolumn{2}{|l|}{ DNMT1 } & Increased & $\begin{array}{l}\text { Maintenance DNA } \\
\text { methyltranferase }\end{array}$ & [38] \\
\hline \multicolumn{2}{|l|}{ DNMT3A } & Increased & $\begin{array}{l}\text { De novo DNA } \\
\text { methyltranferase }\end{array}$ & [39] \\
\hline & DNMT3B & Increased & $\begin{array}{l}\text { De novo DNA } \\
\text { methyltranferase }\end{array}$ & [39] \\
\hline \multicolumn{5}{|l|}{ Histone modification } \\
\hline $\begin{array}{l}\text { Gene or } \\
\text { histone-modifying } \\
\text { enzyme }^{\dagger}\end{array}$ & $\begin{array}{l}\text { Gene or } \\
\text { histone-modifying } \\
\text { enzyme expression level } \\
\text { in pituitary }\end{array}$ & Altered histone mark(s) & $\begin{array}{l}\text { Gene or } \\
\text { histone-modifying } \\
\text { enzyme function }\end{array}$ & \\
\hline PTTG & Increased & H3 acetylation (increased) & $\begin{array}{l}\text { Cell cycle progression, } \\
\text { proliferation, } \\
\text { angiogenesis, } \\
\text { chromosomal stability }\end{array}$ & [40] \\
\hline$B M P-4$ & Decreased & $\begin{array}{l}\text { H3K27 methylation } \\
\text { (increased) }\end{array}$ & $\begin{array}{l}\text { Cell proliferation, } \\
\text { development }\end{array}$ & [41] \\
\hline HDAC $11^{\dagger}$ & Increased & Not evaluated & Histone deacetylase & [42] \\
\hline SIRT1† & Increased & Not evaluated & & [43] \\
\hline SIRT3, 4 and $7^{\dagger}$ & Decreased & Not evaluated & & [43] \\
\hline $\mathrm{EZH}^{\dagger}$ & Increased & $\begin{array}{l}\text { H3K27 methylation } \\
\text { (increased) }\end{array}$ & $\begin{array}{l}\text { Histone } \\
\text { methyltransferase }\end{array}$ & [44] \\
\hline $\mathrm{RIZ1}^{\dagger}$ & Decreased & $\begin{array}{l}\text { H3K4 methylation } \\
\text { (decreased) } \\
\text { H3K9 methylation } \\
\text { (decreased) } \\
\text { H3K27 methylation } \\
\text { (increased) }\end{array}$ & & [45] \\
\hline miRNA-mediated silencing & & & & \\
\hline miRNA & Target gene & $\begin{array}{l}\text { miRNA expression level in } \\
\text { pituitary }\end{array}$ & Gene function & Ref. \\
\hline $\begin{array}{l}\text { miR-107 } \\
\text { miR-34 }\end{array}$ & AIP & Increased & $\begin{array}{l}\text { Receptor-mediated } \\
\text { signaling }\end{array}$ & [46] \\
\hline
\end{tabular}


Table 1. Overview of dysregulated epigenetic mechanisms in pituitary tumors (cont.).

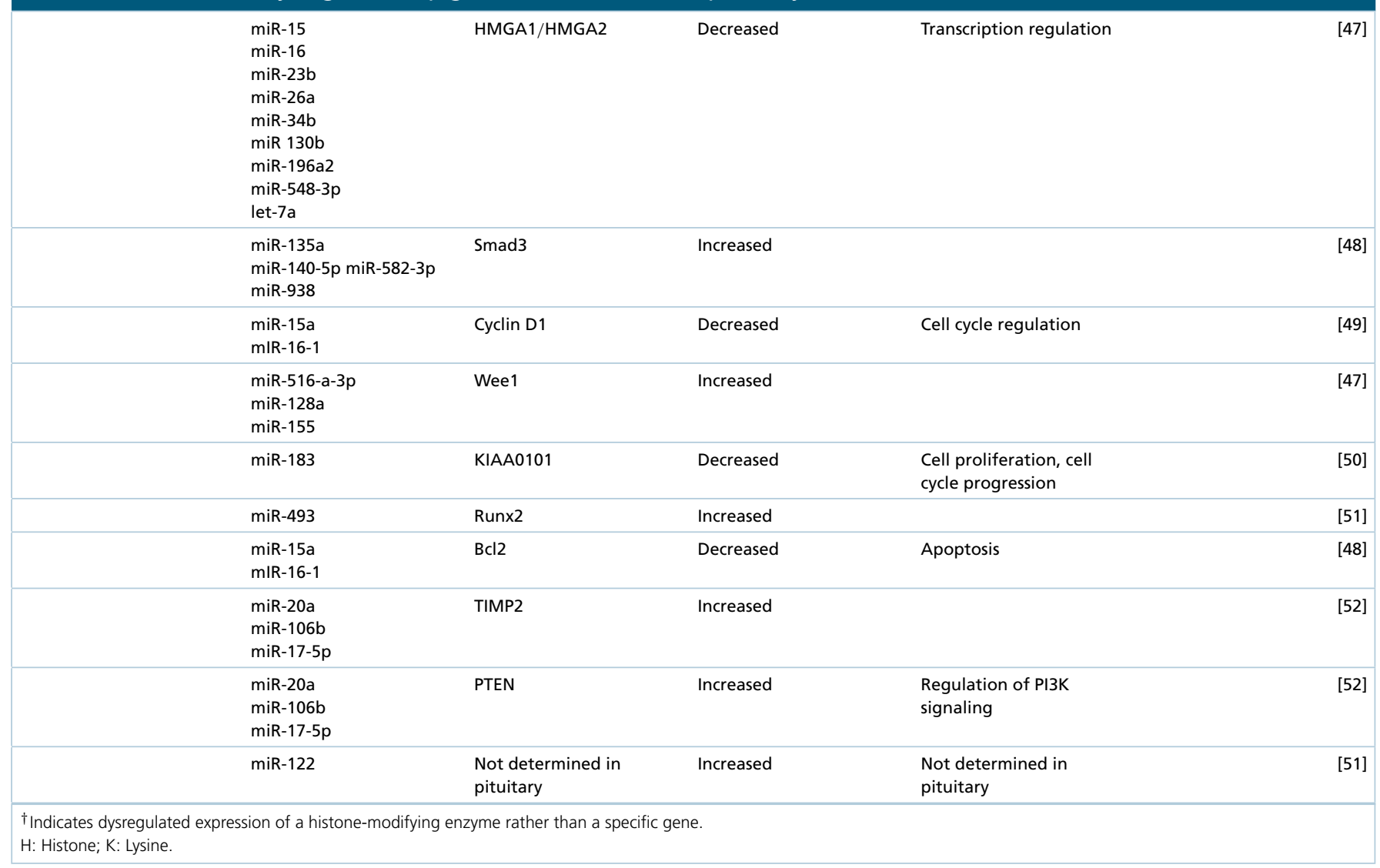

Earlier studies investigating DNA methylation in pituitary adenomas utilized a candidate gene approach that relied on methylation-specific PCR. Advances in next-generation sequencing (NGS) technology and bioinformatics analyses have allowed for genome-scale profiling of the methylome to be performed across different pituitary tumor subtypes. To date, at least five such genome-scale studies have been published, investigating the association between methylation frequency, gene expression and clinical behavior in pituitary adenomas [37,53-56]. In a study of NF adenomas, hypomethylated $\mathrm{CpGs}$ in invasive tumors were significantly more prevalent than hypermethylated sites, with 339 CpGs showing a complete distinction between the two tumor types [54]. However, in a larger study of 34 non-functioning pituitary adenomas the same profiles were not observed, with no association between methylation profile and degree of invasiveness [56]. Furthermore, when the authors examined their list of top differentially methylated probes (DMPs) related to invasive growth, no commonalities were found when compared with the DMPs reported in two additional studies of genome-wide methylation analysis [53,54]. It is likely that differences in genomic techniques, analytical approaches and sample sizes may explain some of these discrepancies and this highlights the importance of detailed reporting of these factors when large-scale analysis is performed. A more recent study has also reported that DNA methylation profiling could discriminate between three different pituitary adenoma subtypes in 48 patients (GH-secreting, ACTH-secreting and NF pituitary tumors) although these findings require confirmation in a larger number of samples [55]. Moreover, the functional significance of methylation at these loci in terms of gene expression changes, and the role that these genes play in pituitary tumorigenesis, remains to be elucidated.

Aberrant expression of the DNMT enzymes has also been reported in pituitary adenomas. In a study of 63 human pituitary adenomas, overexpression of DNMT1 and DNMT3A was detected and a significant association with tumor invasiveness was observed [38]. Conversely, in another study DNMT3B, but not DNMT1 or DNMT3A, was expressed at significantly higher levels in neoplastic compared with normal pituitary tissue [39]. Interestingly, in mouse pituitary cell lines, the effect of increased DNMT3B expression on the downregulation of tumor suppressors $\mathrm{Rb}, \mathrm{p} 21^{\mathrm{Cip} 1}$ and $\mathrm{p} 27^{\mathrm{Kip} 1}$ was found to be mediated through histone modification rather than DNA methylation [39]. 


\section{Histone modifications}

Initial studies of the pituitary tumor epigenome focused largely on DNA methylation; however, recent studies have explored the landscape of post-translational histone modifications. In the nucleus, DNA is wrapped around an octamer of four core histone proteins ( $\mathrm{H} 2 \mathrm{~A}, \mathrm{H} 2 \mathrm{~B}, \mathrm{H} 3$ and $\mathrm{H} 4)$ to form nucleosome subunits that are condensed into chromatin (Figure 1). Highly condensed chromatin (heterochromatin) is inaccessible to transcription factors and transcriptional machinery, while open chromatin (euchromatin) is associated with transcriptional activation. Chromatin structure and accessibility can be regulated by covalent modifications of histone tails (Figure 1). Acetylation of histone tails, particularly lysine K9 and K14 on H3 (H3K9 and H3K14) by histone acetyltransferases (HATs) is associated with euchromatin and gene activation [57]. Methylation of histone tails by histone methyltransferases (HMTs) can repress or activate transcription depending on the specific residue that is methylated and the number of methyl moieties attached. For example, while trimethylation of $\mathrm{K} 4 \mathrm{on} \mathrm{H} 3$ (H3K4Me3) is associated with active gene transcription, di- and trimethylation of $\mathrm{K} 9$ on $\mathrm{H} 3(\mathrm{H} 3 \mathrm{~K} 9 \mathrm{Me} 2 / 3)$ is associated with transcriptional silencing [57]. HATs and HMTs responsible for catalyzing these modifications are referred to as 'writers', while histone deacetylases (HDACs) and histone demethylases (HDMs) that remove these marks are known as 'erasers'. Epigenetic 'reader' proteins containing lysine-binding motifs (e.g., bromodomains, chromodomains and tudor domains) can also bind to specific histone marks and recruit other regulators of gene transcription and chromatin structure [58].

Dysregulated histone acetylation is reported in pituitary tumors in studies utilizing genome-wide techniques including chromatin immunoprecipitation (ChIP). For example, the oncogenic PTTG gene was found to be overexpressed in pituitary adenomas and upregulated by the HAT p300 in cell lines via increased $\mathrm{H} 3$ acetylation at the PTTG promoter [40]. In addition, a significant global increase in $\mathrm{H} 3 \mathrm{~K} 9$ acetylation (an active epigenetic mark) was observed in typical and atypical pituitary adenomas compared with normal pituitary, with a significant correlation between tumor severity and $\mathrm{H} 3 \mathrm{~K} 9$ acetylation status [59]. Overexpression of HDAC11 has also been observed in pituitary tumors, and associated with downregulation of $\mathrm{p} 53$ expression in cell lines [42]. Expression of the sirtuin (SIRT) family of HDACs was also noted to differ between somatotropinomas and NF pituitary adenomas [43]. SIRT1 was overexpressed in somatotropinomas, while SIRT3, SIRT4 and SIRT7 were underexpressed in NFPAs [43]. Although SIRT1 overexpression correlated with smaller tumor diameter, and SIRT3 underexpression correlated with larger tumor size, no association was seen between SIRT expression and Ki-67 proliferative index [43]. Thus, the role of histone acetylation activity in pituitary tumors and its role, if any, in pituitary tumorigenesis requires further investigation.

Aberrant activity of the HMT EZH2 has been implicated in numerous cancers, and its expression was found to be upregulated in a large cohort of 165 human pituitary tumors, with almost no staining seen in normal pituitary tissue [44]. Furthermore, EZH2 expression levels demonstrated a positive correlation with Ki-67 proliferation indices [44]. RIZ1, which acts as a tumor suppressor and an HMT, was found to be downregulated in invasive pituitary adenomas, compared with noninvasive tumors [45]. Lower RIZ1 expression also correlated with decreased methylation of $\mathrm{H} 3 \mathrm{~K} 4$ and enhanced methylation levels of $\mathrm{H} 3 \mathrm{~K} 27$ in noninvasive adenomas, as well as significantly improved survival [45]. This suggests that alterations in these histone marks leads to dysregulation of putative downstream target genes required for pituitary tumor cell survival, proliferation and migration. However, the target genes affected by the dysregulated expression of histone modifying enzymes such as EZH2 and RIZ1 and their functional relevance to pituitary tumor initiation and development remain unknown.

\section{MicroRNAs}

MicroRNAs (miRNAs) are short, noncoding RNAs that post-transcriptionally regulate gene expression by basepairing with complementary sequences at the $3^{\prime}$-untranslated regions of mRNA and within coding regions (Figure 1). They play important roles in fundamental biological processes including cell proliferation, differentiation and apoptosis [60]. miRNAs can have oncogenic or tumor suppressive roles in pituitary tumors (Table 1). For example, overexpression of miR-107 and miR-34 has been shown to inhibit protein expression of AIP [46]. Wee1 kinase, an important cell cycle inhibitor of Cdk1, was identified as a target of miR-516-a-3p, miR-128a and miR-155, all of which were upregulated in pituitary adenomas [47]. In addition, five miRNAs (miR-135a, miR-140-5p, miR582-3p, miR-582-5p and miR-938) were overexpressed in NF pituitary adenomas and were predicted, through in silico analysis, to downregulate the TGF- $\beta$ signaling pathway by targeting Smad3 [48]. In contrast, downregulated miRNAs target oncogenic proteins. For example, HMGA1 and HMGA2, which are overexpressed across pituitary adenoma subtypes and contribute to tumorigenesis by enhancement of E2F1 transcription factor activity, are 
targeted by miR-15, miR-16, miR-23b, miR-26a, miR-34b, miR 130b, miR-196a2, miR-548-3p and let-7a [61], all of which are downregulated in pituitary tumors compared with normal tissue [61]. Decreased expression of miR-15a and miR-16-1 in GH and PRL-secreting adenomas has been shown to correlate with increased tumor diameter [62]. Both miRNAs may target the antiapoptotic Bcl2 protein and the cell cycle protein cyclin D1, which are overexpressed in a significant proportion of pituitary adenomas $[48,49]$.

More recently, the advent of high-throughput molecular biology techniques such as microarrays and NGS-based methods has allowed for extensive miRNA profiling studies to be conducted, leading to a growing repertoire of miRNA expression profiles across various pituitary tumor subtypes. Despite the advantages of these techniques, miRNA expression profiles of identical tumor samples may show varying concordance across different platforms, and the functional consequences of these changes have rarely been studied [63]. This underscores the importance of validating the functional relevance and biological importance of observed miRNA (and other epigenetic) alterations with in vitro mechanistic studies and in vivo studies utilizing currently available animal models of pituitary neoplasia [64].

\section{Pituitary carcinoma}

Pituitary carcinomas represent $0.1-0.2 \%$ of all pituitary tumors and have a 1 -year mortality rate of $66 \%[65]$. Compared with pituitary adenomas, few studies have explored the epigenome of pituitary carcinomas, likely due to the rarity of cases and lack of available tumor tissue for analysis. One study investigating DNA methylation in pituitary carcinomas reported hypermethylation of the $M G M T$ reporter in $33 \%$ of samples; however, methylation status was not always concordant with $M G M T$ expression [66]. A study investigating differentially expressed miRNAs in corticotroph carcinomas compared with pituitary adenomas showed significant overexpression of miR122, although the mechanisms linking this to carcinogenesis were not elucidated [51]. In addition, upregulation of miR-20a, miR-106b and miR-17-5p was reported to be associated with pituitary carcinoma metastases via attenuation of PTEN and TIMP2 [52]. Furthermore, downregulation of miR-183 in a small combined sample of pituitary carcinomas and invasive prolactinomas, demonstrated that miR-183 directly targets the cell cycle activator KIAA0101 [50]. Overall, attempts to identify predictive and prognostic pituitary carcinoma-specific biomarkers have been unsuccessful due to the small number of studies and the finding that markers identified in malignant tumors are also differentially expressed in aggressive adenomas.

\section{Therapeutic potential}

With the exception of prolactinomas, which are treated with dopamine agonists, most pituitary tumors undergo surgical resection as first-line treatment [67]. Approximately $80 \%$ of nonfunctioning and GH-secreting and $25 \%$ of PRL-secreting adenomas are macroadenomas ( $\geq 1 \mathrm{~cm}$ in diameter) at presentation [68]. These tumors often invade surrounding structures, including the cavernous sinus or dura mater, and incomplete resection is common with reported cure rates of $30 \%$, even in specialized centers [69]. Patients with recurrent disease require additional therapies beyond surgery, including radiation, stereotactic radiosurgery and hormone-regulating medications, although many patients still do not achieve remission, meaning novel therapies with greater efficacy are required [69]. Unlike genetic mutations, epigenetic changes are reversible, and therefore drugs targeting epigenetic modifications could be of valuable therapeutic potential in pituitary tumors.

Epigenetic drugs (also known as 'epidrugs') fall into two major classes: broad 'reprogrammers' and targeted compounds [58]. Broad reprogrammers include DNMT inhibitors (DNMTi) and HDAC inhibitors (HDACi). These have large-scale effects on the epigenome and reverse genome-wide cancer-specific gene expression alterations [58]. The DNMTi azacytidine and decitabine were the first epidrugs to be approved by the US FDA for use in myelodysplastic syndrome and acute myeloid leukemias [70]. At least four HDACi have also been approved for the treatment of cutaneous T-cell lymphoma and multiple myeloma [70]. One of the concerns raised about broad reprogrammers is the potential for off-target deleterious side effects due to nonspecific effects on the entire genome. Targeted therapies may overcome this issue as they are directed against specific aberrantly expressed epigenetic modifying enzymes. These include HMT inhibitors (HMTi) and histone demethylase inhibitors (HDMi), many of which are currently being evaluated in early phase clinical trials for hematological and solid malignancies [70]. The armamentarium of epidrugs has recently extended beyond inhibitors of epigenetic writers and erasers to include a third class of compounds that target epigenetic readers, including the bromodomain and extraterminal domain (BET) family of proteins, which upregulate oncogene expression in various cancers [71]. 
Despite the excitement that epidrugs have generated in the oncology field, few preclinical and no clinical studies have evaluated their use in pituitary tumors [41,72-75]. An early study demonstrated beneficial effects of the HDACi suberoylanilide hydroxamic acid (SAHA) with decreased proliferation and increased apoptosis in the GH- and PRLsecreting GH3 rat pituitary adenoma cell line [75]. In addition, administration of SAHA decreased cell viability and ACTH release in murine ACTH-secreting tumor (AtT-20) cells and human-derived corticotroph tumor (hCtT) cells (both of which are used as in vitro experimental models of Cushing's disease as they secrete ACTH) via downregulation of pro-opiomelanocortin [74]. Similar results were observed with the HDACi trichostatin A, which also decreased AtT-20 cell proliferation via downregulation of PTTG1 and inhibited ACTH production [76]. These findings suggest the potential utility of using HDACi to treat recurrent/unremitting Cushing's disease. Over 30 pituitary tumor animal models (mostly murine) have been generated, and the findings of the aforementioned in vitro studies should be validated in vivo prior to clinical testing in humans [64].

\section{Future perspective}

Significant advances have been made in the assessment of epigenetic dysregulation in pituitary adenomas. Although the majority of studies to date have focused on aberrant DNA methylation-induced gene silencing, much remains to be understood regarding the impact of other mechanisms such as histone modification. In addition to methylation and acetylation, histones are also subject to modifications such as sumoylation, ubiquitination and phosphorylation [57]. However, the impact of these post-translational modifications on pituitary tumorigenesis is not well described. Furthermore, while studies of noncoding RNAs in pituitary tumors have largely focused on miRNAs, the contribution of other classes of small RNAs, including small nuclear RNAs and long noncoding RNAs warrants investigation. Over the past decade, the rapid development and decreasing costs of NGS-based technologies that are able to assess genome-wide histone mark binding (e.g., ChIP coupled with sequencing [ChIP-Seq]) and chromatin accessibility (e.g., assay for transposase-accessible chromatin using sequencing [ATAC-Seq] and DNase I hypersensitive sites sequencing [DNase-Seq]) has facilitated the integrative analysis of epigenetics data in various tumors [77]. Application of these technologies to assess pituitary and other tumors may lead to the identification of novel therapeutic targets. The majority of pituitary tumors are benign; however, a subset may behave aggressively, and early prediction of invasiveness or malignant behavior remains a challenge. Comparatively little is known about the epigenetic landscape of pituitary carcinomas and given their rarity, multicenter collaboration is needed to collate enough samples for analysis. Detailed epigenetic profiling of both benign and aggressive tumors may, in the future, lead to the identification of reliable biomarkers that could be used to guide diagnosis, prognostication and management, akin to those utilized in other intracranial tumors such as gliomas and meningiomas [78,79]. A potentially exciting area of future research will be the preclinical, and eventually clinical, investigation of epidrugs that target specific epigenetic modifying enzymes (e.g., EZH2) that are aberrantly expressed in pituitary tumors. These studies could lead to the translation of novel therapies from the bench to clinical practice and would provide a much-needed treatment option for patients with refractory or recurrent pituitary tumors.

\section{Conclusion}

In this review, we provide an overview of epigenetic dysregulation in benign and malignant pituitary tumors. The outlined studies describe alterations in tumor suppressor genes and oncogenes, in association with aberrant DNA methylation, histone modifications and miRNA expression. However, further work is still required to uncover the specific mechanisms through which these alterations contribute to tumor development and progression. Further elucidation of these mechanisms and preclinical testing of emerging epigenetic drugs may offer new avenues for the medical management of patients with pituitary tumors.

\section{Financial \& competing interests disclosure}

The authors have no relevant affiliations or financial involvement with any organization or entity with a financial interest in or financial conflict with the subject matter or materials discussed in the manuscript. This includes employment, consultancies, honoraria, stock ownership or options, expert testimony, grants or patents received or pending, or royalties.

No writing assistance was utilized in the production of this manuscript.

\section{Open access}

This work is licensed under the Attribution-NonCommercial-NoDerivatives 4.0 Unported License. To view a copy of this license, visit http://creativecommons.org/licenses/by-nc-nd/4.0/ 
Summary points

- The majority of pituitary tumors are sporadic adenomas that harbor few somatic mutations.

- Increasing evidence points toward epigenetic dysregulation in pituitary tumors, including aberrant DNA methylation, histone modifications and inappropriate expression of microRNAs.

- Promoters of tumor suppressor genes involved in cell cycle regulation, apoptosis and DNA damage response may be hypermethylated in pituitary adenomas. However, a correlation between methylation status and downregulated gene expression is often not observed.

- Global and specific alterations in histone acetylation and methylation patterns have been observed in pituitary adenomas and variably correlate with size, proliferation and survival.

- MicroRNAs may have tumor suppressive or oncogenic roles in pituitary tumors, although the functional relevance of most miRNA alterations requires validation.

- Compared with pituitary adenomas, very few studies have explored the epigenomic landscape of pituitary carcinomas.

- Preclinical data suggest the utility of using histone deacetylase inhibitors to treat recurrent/unremitting Cushing's disease; however, these findings require validation in animal studies.

- Few preclinical studies and no clinical studies to date have evaluated the effects of epigenetic drugs in the treatment of pituitary tumors.

- Future research directions should include integrative analysis of the pituitary tumor epigenome using next-generation sequencing technologies, the identification of reliable biomarkers and further investigation of novel epigenetic compounds in preclinical and clinical studies.

\section{References}

Papers of special note have been highlighted as: $\bullet$ of interest; $\bullet \bullet$ of considerable interest

1. Gittleman H, Ostrom QT, Farah PD et al. Descriptive epidemiology of pituitary tumors in the United States, 2004-2009. J. Neurosurg. 121(3), 527-535 (2014).

2. Fernandez A, Karavitaki N, Wass JA. Prevalence of pituitary adenomas: a community-based, cross-sectional study in Banbury (Oxfordshire, UK). Clin. Endocrinol. (Oxf.) 72(3), 377-382 (2010).

3. Yates CJ, Lines KE, Thakker RV. Molecular genetic advances in pituitary tumor development. Expert Rev. Endocrinol. Metab. 10(1), 35-53 (2015).

4. Kirschner LS, Carney JA, Pack SD et al. Mutations of the gene encoding the protein kinase A type I-alpha regulatory subunit in patients with the Carney complex. Nat. Genet. 26(1), 89-92 (2000).

5. De Laat JM, Dekkers OM, Pieterman CR et al. Long-term natural course of pituitary tumors in patients with MEN1: results from the DutchMEN1 study group (DMSG). J. Clin. Endocrinol. Metab. 100(9), 3288-3296 (2015).

6. Vierimaa $\mathrm{O}$, Georgitsi M, Lehtonen $\mathrm{R}$ et al. Pituitary adenoma predisposition caused by germline mutations in the AIP gene. Science 312(5777), 1228-1230 (2006).

7. Song ZJ, Reitman ZJ, Ma ZY et al. The genome-wide mutational landscape of pituitary adenomas. Cell Res. 26(11), 1255-1259 (2016).

8. Bi WL, Horowitz P, Greenwald NF et al. Landscape of genomic alterations in pituitary adenomas. Clin. Cancer Res. 23(7), 1841-1851 (2017).

9. Newey PJ, Nesbit MA, Rimmer AJ et al. Whole-exome sequencing studies of nonfunctioning pituitary adenomas. J. Clin. Endocrinol. Metab. 98(4), E796-E800 (2013).

10. Reincke M, Sbiera S, Hayakawa A et al. Mutations in the deubiquitinase gene USP8 cause Cushing's disease. Nat. Genet. 47(1), 31-38 (2015).

11. Ma ZY, Song ZJ, Chen JH et al. Recurrent gain-of-function USP8 mutations in Cushing's disease. Cell Res. 25(3), 306-317 (2015).

12. Chen J, Jian X, Deng S et al. Identification of recurrent USP48 and BRAF mutations in Cushing's disease. Nat. Commun. 9(1), 3171 (2018).

13. Landis CA, Masters SB, Spada A, Pace AM, Bourne HR, Vallar L. GTPase inhibiting mutations activate the alpha chain of Gs and stimulate adenylyl cyclase in human pituitary tumors. Nature 340(6236), 692-696 (1989).

14. Okano M, Bell DW, Haber DA, Li E. DNA methyltransferases Dnmt3a and Dnmt3b are essential for de novo methylation and mammalian development. Cell. 99(3), 247-257 (1999).

15. Leonhardt H, Page AW, Weier HU, Bestor TH. A targeting sequence directs DNA methyltransferase to sites of DNA replication in mammalian nuclei. Cell 71(5), 865-873 (1992).

16. Bird AP. CpG-rich islands and the function of DNA methylation. Nature 321(6067), 209-213 (1986).

17. Craig JM, Bickmore WA. The distribution of CpG islands in mammalian chromosomes. Nat. Genet. 7(3), 376-382 (1994). 
18. Fuks F, Hurd PJ, Wolf D, Nan X, Bird AP, Kouzarides T. The methyl-CpG-binding protein MeCP2 links DNA methylation to histone methylation. J. Biol. Chem. 278(6), 4035-4040 (2003).

19. Yoshino A, Katayama Y, Ogino A et al. Promoter hypermethylation profile of cell cycle regulator genes in pituitary adenomas. $J$. Neurooncol. 83(2), 153-162 (2007).

20. Seemann N, Kuhn D, Wrocklage C et al. CDKN2A/p16 inactivation is related to pituitary adenoma type and size. J. Pathol. 193(4), 491-497 (2001).

21. Jaffrain-Rea ML, Ferretti E, Toniato E et al. p16 (INK4a, MTS-1) gene polymorphism and methylation status in human pituitary tumors. Clin. Endocrinol. (Oxf.) 51(3), 317-235 (1999).

22. Ogino A, Yoshino A, Katayama Y et al. The p15(INK4b)/p16(INK4a)/RB1 pathway is frequently deregulated in human pituitary adenomas. J. Neuropathol. Exp. Neurol. 64(5), 398-403 (2005).

23. Bello MJ, De Campos JM, Isla A, Casartelli C, Rey JA. Promoter CpG methylation of multiple genes in pituitary adenomas: frequent involvement of caspase-8. Oncol. Rep. 15(2), 443-448 (2006).

24. Kirsch M, Morz M, Pinzer T, Schackert HK, Schackert G. Frequent loss of the CDKN2C (p18INK4c) gene product in pituitary adenomas. Genes Chromosomes Cancer 48(2), 143-154 (2009).

25. Hossain MG, Iwata T, Mizusawa N et al. Expression of p18(INK4C) is downregulated in human pituitary adenomas. Endocr. Pathol. 20(2), 114-121 (2009).

26. Simpson DJ, Hibberts NA, Mcnicol AM, Clayton RN, Farrell WE. Loss of pRb expression in pituitary adenomas is associated with methylation of the RB1 CpG island. Cancer Res. 60(5), 1211-1216 (2000).

27. Bahar A, Bicknell JE, Simpson DJ, Clayton RN, Farrell WE. Loss of expression of the growth inhibitory gene GADD45gamma, in human pituitary adenomas, is associated with CpG island methylation. Oncogene 23(4), 936-944 (2004).

28. Zhang X, Sun H, Danila DC et al. Loss of expression of GADD 45 gamma, a growth inhibitory gene, in human pituitary adenomas: implications for tumorigenesis. J. Clin. Endocrinol. Metab. 87(3), 1262-1267 (2002).

29. Simpson DJ, Clayton RN, Farrell WE. Preferential loss of Death Associated Protein kinase expression in invasive pituitary tumors is associated with either CpG island methylation or homozygous deletion. Oncogene 21(8), 1217-1224 (2002).

30. Bahar A, Simpson DJ, Cutty SJ et al. Isolation and characterization of a novel pituitary tumor apoptosis gene. Mol. Endocrinol. 18(7), 1827-1839 (2004).

31. Qian ZR, Sano T, Yoshimoto K et al. Inactivation of RASSF1A tumor suppressor gene by aberrant promoter hypermethylation in human pituitary adenomas. Lab. Invest. 85(4), 464-473 (2005).

32. Peng H, Liu H, Zhao S, Wu J, Fan J, Liao J. Silencing of RASSF3 by DNA hypermethylation is associated with tumorigenesis in somatotroph adenomas. PLoS ONE 8(3), e59024 (2013).

33. Qian ZR, Sano T, Yoshimoto K et al. Tumor-specific downregulation and methylation of the $C D H 13$ (H-cadherin) and $C D H 1$ (E-cadherin) genes correlate with aggressiveness of human pituitary adenomas. Mod. Pathol. 20(12), 1269-1277 (2007).

34. Zhu X, Lee K, Asa SL, Ezzat S. Epigenetic silencing through DNA and histone methylation of fibroblast growth factor receptor 2 in neoplastic pituitary cells. Am. J. Pathol. 170(5), 1618-1628 (2007).

35. Zhao J, Dahle D, Zhou Y, Zhang X, Klibanski A. Hypermethylation of the promoter region is associated with the loss of $M E G 3$ gene expression in human pituitary tumors. J. Clin. Endocrinol. Metab. 90(4), 2179-2186 (2005).

36. Valiulyte I, Steponaitis G, Skiriute D, Tamasauskas A, Vaitkiene P. Signal transducer and activator of transcription 3 (STAT3) promoter methylation and expression in pituitary adenoma. BMC Med. Genet. 18(1), 72 (2017).

37. Duong CV, Emes RD, Wessely F, Yacqub-Usman K, Clayton RN, Farrell WE. Quantitative, genome-wide analysis of the DNA methylome in sporadic pituitary adenomas. Endocr. Relat. Cancer 19(6), 805-816 (2012).

-. This is the first study to report genome-wide DNA methylation changes in sporadic pituitary adenoma subtypes and investigated the relationship between methylation and transcipt expression.

38. Ma HS, Wang EL, Xu WF et al. Overexpression of DNA (Cytosine-5)-methyltransferase 1 (DNMT1) and DNA (Cytosine-5)-methyltransferase 3A (DNMT3A) is associated with aggressive behavior and hypermethylation of tumor suppressor genes in human pituitary adenomas. Med. Sci. Monit. 24, 4841-4850 (2018).

39. Zhu X, Mao X, Hurren R, Schimmer AD, Ezzat S, Asa SL. Deoxyribonucleic acid methyltransferase 3B promotes epigenetic silencing through histone 3 chromatin modifications in pituitary cells. J. Clin. Endocrinol. Metab. 93(9), 3610-3617 (2008).

40. Li T, Huang H, Huang B, Huang B, Lu J. Histone acetyltransferase p300 regulates the expression of human pituitary tumor transforming gene (bPTTG). J. Genet. Genomics 36(6), 335-342 (2009).

41. Yacqub-Usman K, Duong CV, Clayton RN, Farrell WE. Epigenomic silencing of the BMP-4 gene in pituitary adenomas: a potential target for epidrug-induced re-expression. Endocrinology 153(8), 3603-12 (2012).

42. Wang W, Fu L, Li S, Xu Z, Li X. Histone deacetylase 11 suppresses p53 expression in pituitary tumor cells. Cell Biol. Int. 41(12), 1290-1295 (2017). 
43. Grande IPP, Amorim P, Freire A et al. Differential gene expression of sirtuins between somatotropinomas and nonfunctioning pituitary adenomas. Pituitary. 21(4), 355-361 (2018).

44. Schult D, Holsken A, Siegel S et al. EZH2 is highly expressed in pituitary adenomas and associated with proliferation. Sci. Rep. 5, 16965 (2015).

-. Shows overexpression of EZH2 in a large cohort of pituitary tumors, Compared with normal pituitary, using immunohistochemistry. A positive correlation was also seen between EZH2 expression and the proliferation marker Ki-67.

45. Xue Y, Chen R, Du W, Yang F, Wei X. RIZ1 and histone methylation status in pituitary adenomas. Tumour Biol. 39(7), 1010428317711794 (2017).

46. D'angelo D, Palmieri D, Mussnich P et al. Altered microRNA expression profile in human pituitary GH adenomas: downregulation of miRNA targeting HMGA1, HMGA2, and E2F1. J. Clin. Endocrinol. Metab. 97(7), E1128-E1138 (2012).

47. Butz H, Liko I, Czirjak $S$ et al. Downregulation of Wee1 kinase by a specific subset of microRNA in human sporadic pituitary adenomas. J. Clin. Endocrinol. Metab. 95(10), E181-E191 (2010).

48. Butz H, Liko I, Czirjak S et al. MicroRNA profile indicates downregulation of the TGFbeta pathway in sporadic non-functioning pituitary adenomas. Pituitary. 14(2), 112-124 (2011).

49. Lines KE, Newey PJ, Yates CJ et al. MiR-15a/miR-16-1 expression inversely correlates with cyclin D1 levels in Men1 pituitary NETs. J. Endocrinol. (2018) doi:10.1530/joe-18-0278 (Epub ahead of print).

50. Roche M, Wierinckx A, Croze $S$ et al. Deregulation of miR-183 and KIAA0101 in aggressive and malignant pituitary tumors. Front. Med. (Lausanne) 2, 54 (2015)

51. Stilling G, Sun Z, Zhang S et al. MicroRNA expression in ACTH-producing pituitary tumors: upregulation of microRNA-122 and -493 in pituitary carcinomas. Endocrine 38(1), 67-75 (2010).

52. Wei Z, Zhou C, Liu M et al. MicroRNA involvement in a metastatic non-functioning pituitary carcinoma. Pituitary 18(5), 710-721 (2015).

53. Ling C, Pease M, Shi L et al. A pilot genome-scale profiling of DNA methylation in sporadic pituitary macroadenomas: association with tumor invasion and histopathological subtype. PLoS ONE 9(4), e96178 (2014).

54. Gu Y, Zhou X, Hu F et al. Differential DNA methylome profiling of nonfunctioning pituitary adenomas suggesting tumour invasion is correlated with cell adhesion. J. Neurooncol. 129(1), 23-31 (2016).

55. Salomon MP, Wang X, Marzese DM et al. The epigenomic landscape of pituitary adenomas reveals specific alterations and differentiates among acromegaly, cushing's disease and endocrine-inactive subtypes. Clin. Cancer Res. 24(17), 4126-4136 (2018).

- This recent genome-wide study shows that pituitary adenomas display subtype-specific DNA methylation, and that these profiles can be used to differentiate between tumor types.

56. Kober P, Boresowicz J, Rusetska N et al. DNA methylation profiling in nonfunctioning pituitary adenomas. Mol. Cell. Endocrinol. 473, 194-204 (2018).

57. Jenuwein T, Allis CD. Translating the histone code. Science 293(5532), 1074-1080 (2001).

58. Mohammad HP, Barbash O, Creasy CL. Targeting epigenetic modifications in cancer therapy: erasing the roadmap to cancer. Nat. Med. 25(3), 403-418 (2019).

59. Ebrahimi A, Schittenhelm J, Honegger J, Schluesener HJ. Histone acetylation patterns of typical and atypical pituitary adenomas indicate epigenetic shift of these tumors. J. Neuroendocrinol. 23(6), 525-530 (2011).

60. Jonas S, Izaurralde E. toward a molecular understanding of microRNA-mediated gene silencing. Nat. Rev. Genet. 16(7), 421-433 (2015).

61. Palmieri D, D'angelo D, Valentino T et al. Downregulation of HMGA-targeting microRNAs has a critical role in human pituitary tumorigenesis. Oncogene 31(34), 3857-3865 (2012).

- Shows that the overexpression of HMGA1 and HMGA2 in pituitary tumors occurs as a result of downregulation of $H M G A$-targeting miRNAs. This study also demonstrates the functional significance of these HMGA-targeting miRNAs, by showing that their induced ER expression inhibits cell proliferation.

62. Bottoni A, Piccin D, Tagliati F, Luchin A, Zatelli MC, Degli Uberti EC. miR-15a and miR-16-1 down-regulation in pituitary adenomas. J. Cell. Physiol. 204(1), 280-285 (2005).

63. Darvasi O, Szabo PM, Nemeth K et al. Limitations of high throughput methods for miRNA expression profiles in non-functioning pituitary adenomas. Pathol. Oncol. Res. 25(1), 169-182 (2019).

64. Lines KE, Stevenson M, Thakker RV. Animal models of pituitary neoplasia. Mol. Cell Endocrinol. 421, 68-81 (2016).

-• Provides an overview of $>\mathbf{3 0}$ animal models of pituitary neoplasia, including mouse, rat and zebrafish models, that can be used to investigate pituitary tumorigensis and evaluate novel therapies.

65. Dworakowska D, Grossman AB. Aggressive and malignant pituitary tumors: state-of-the-art. Endocr. Relat. Cancer. 25(11), R559-R575 (2018).

66. Salehi F, Scheithauer BW, Kros JM et al. MGMT promoter methylation and immunoexpression in aggressive pituitary adenomas and carcinomas. J. Neurooncol. 104(3), 647-657 (2011). 
67. Barker FG, 2nd, Klibanski A, Swearingen B. Transsphenoidal surgery for pituitary tumors in the United States, 1996-2000: mortality, morbidity, and the effects of hospital and surgeon volume. J. Clin. Endocrinol. Metab. 88(10), 4709-4719 (2003).

68. Kim JH, Dho YS, Kim YH et al. Developing an optimal follow-up strategy based on the natural history of nonfunctioning pituitary adenomas. J. Neurosurg. 131(2), 333-656 (2018).

69. Kreutzer J, Vance ML, Lopes MB, Laws ER Jr. Surgical management of GH-secreting pituitary adenomas: an outcome study using modern remission criteria. J. Clin. Endocrinol. Metab. 86(9), 4072-4077 (2001).

70. Berdasco M, Esteller M. Clinical epigenetics: seizing opportunities for translation. Nat. Rev. Genet. 20(2), 109-127 (2019).

71. Filippakopoulos P, Qi J, Picaud S et al. Selective inhibition of BET bromodomains. Nature 468(7327), 1067-1073 (2010).

72. Yacqub-Usman K, Duong CV, Clayton RN, Farrell WE. Preincubation of pituitary tumor cells with the epidrugs zebularine and trichostatin A are permissive for retinoic acid-augmented expression of the BMP-4 and D2R genes. Endocrinology 154(5), 1711-1721 (2013).

73. Sukumari-Ramesh S, Singh N, Jensen MA, Dhandapani KM, Vender JR. Anacardic acid induces caspase-independent apoptosis and radiosensitizes pituitary adenoma cells. J. Neurosurg. 114(6), 1681-1690 (2011).

74. Lu J, Chatain GP, Bugarini A et al. Histone deacetylase inhibitor SAHA is a promising treatment of Cushing disease. J. Clin. Endocrinol. Metab. 102(8), 2825-2835 (2017).

75. Sangeetha SR, Singh N, Vender JR, Dhandapani KM. Suberoylanilide hydroxamic acid (SAHA) induces growth arrest and apoptosis in pituitary adenoma cells. Endocrine 35(3), 389-396 (2009).

- This is the first preclinical study to investigate the use of an epigenetic drug for the treatment of pituitary adenoma cells in vitro.

76. Nakada Y, Kageyama K, Sugiyama A et al. Inhibitory effects of trichostatin A on adrenocorticotropic hormone production and proliferation of corticotroph tumor AtT-20 cells. Endocr. J. 62(12), 1083-90 (2015).

77. Jiang S, Mortazavi A. Integrating ChIP-seq with other functional genomics data. Brief Funct. Genomics 17(2), 104-115 (2018).

78. Hegi ME, Diserens AC, Gorlia T et al. MGMT gene silencing and benefit from temozolomide in glioblastoma. N. Engl. J. Med. 352(10), 997-1003 (2005).

79. Sahm F, Schrimpf D, Stichel D et al. DNA methylation-based classification and grading system for meningioma: a multicentre, retrospective analysis. Lancet Oncol. 18(5), 682-694 (2017). 